\section{Volcanic traces}

SIR-Numerous chemical and isotope studies $^{1,2}$ of xenolith samples carried to the surface by volcanic eruptions have revealed a common pattern of enrichment in incompatible trace elements, accompanied by only minor amounts of basaltic components such as silicon, aluminium, calcium and titanium. Termed 'metasomatic' enrichment (especially where the addition of the light rare-earth elements is involved), this process has been attributed to the action of mantle fluids enriched in trace elements, capable of modifying the content of trace elements in rocks through which they pass without discernible effect on the composition of major elements ${ }^{2}$. Support for this view comes from the common occurrence of $\mathrm{CO}_{2}$-rich fluid inclusions in xenoliths and experimental indications of high rare earth solubility in both carbonate melt and $\mathrm{CO}_{2}$ (refs 3,4). However, measurements of trace element solubilities in $\mathrm{CO}_{2}$ at high pressure and temperature remain in conflict. Meen et al. recently failed to substantiate the earlier experimental results: their experiments suggest distribution coefficients $\mathrm{K}_{\mathrm{D}}{ }^{\text {con/diopside }}$ for $\mathrm{Nd}$ at least as low as 0.5 and probably less then 0.05 at high pressures and temperatures, implying a limited role for $\mathrm{CO}_{2}$-rich fluids as agents of rare-earth element transport in the mantle. Our isotope measurements on xenolith samples support the experimental conclusions reached by Meen et al. ${ }^{5}$.

Helium isotopes are ideal tracers of fluid movement in the crust and mantle, partitioning strongly into fluid in equilibrium with melt or solid phases ${ }^{6}$. Helium in xenolith samples resides predominantly in their (invariably $\mathrm{CO}_{2}$-rich) fluid inclusions $^{7-9}$. The isotope covariation of neodymium with $\mathrm{He}$ provides a test of the fluid-phase partitioning. behaviour of $\mathrm{Nd}$ - if mantle fractionations of $\mathrm{U} / \mathrm{He}$ and

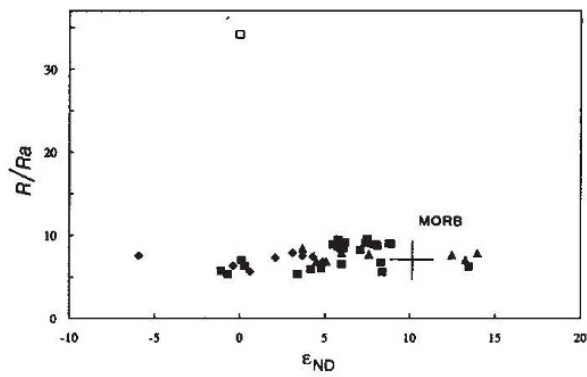

$\mathrm{He}-\mathrm{Nd}$ isotope relationships in ultramafic xenoliths. The wide range of $\mathrm{Nd}$ isotope compositions (expressed as $\varepsilon_{\mathrm{Nd}}=10^{4}\left({ }^{143} \mathrm{Nd} /{ }^{144} \mathrm{Nd}\right.$ sample $\left.{ }^{143} \mathrm{Nd} / /^{144} \mathrm{Nd}_{\mathrm{CHUR}}-1\right)$, where CHUR indicates a reservoir with chondritic ${ }^{147} \mathrm{Sm} /{ }^{144} \mathrm{Nd}$ ratio) contrasts with uniform, mid-ocean-ridgebasalt-like $\mathrm{He}$ isotope compositions (sample ${ }^{3} \mathrm{He} /{ }^{4} \mathrm{He}$ ratios $(R)$ normalized to the atmospheric ratio $(R a)$. Note that radiogenic He plots at low $R / R a$ values (less than 0.1). Diamonds, continental samples; triangles, convergent margin samples; closed squares, ocean island samples; open square, primitive components.
$\mathrm{Sm} / \mathrm{Nd}$ remain coupled, and $\mathrm{Nd}$ were to move with $\mathrm{He}$ in metasomatic fluids, $\mathrm{He}$ and $\mathrm{Nd}$ isotope signatures should vary sympathetically.

$\mathrm{He}$ and $\mathrm{Nd}$ isotope data for ultramafic xenoliths have been reported by us $^{7-9}:$ in the figure we illustrate these results for an extensive set of continental and oceanic samples. Over an extreme range of sample $\mathrm{Nd}$ isotope compositions, He maintains a strikingly uniform composition indistinguishable from that of the convective mantle as sampled by mid-ocean ridge basalts. The wide-ranging $\mathrm{Nd}$ isotope compositions of the xenoliths may result from inputs from other geochemical reservoirs ${ }^{8}$, or from long-term isolation in the lithosphere. However, they are decoupled from $\mathrm{He}$ isotope effects. Neither primitive ${ }^{3} \mathrm{He}$-rich, nor ${ }^{4} \mathrm{He}$-rich compositions indicative of ageing in the lithosphere, are observed in the samples. The He and Nd carried by the samples come from separate reservoirs, with separate fractionation histories. The data imply that these elements do not move together in metasomatic fluids.

Decoupling of these systems may be thought of as reflecting addition to the lithospheric mantle of a He-rich, Nd-poor component. The high $\mathrm{He}$ component is likely to have been associated with $\mathrm{CO}_{2}$, now present in fluid inclusions.

The xenolith data document widespread access of volatiles from the convecting mantle to the lithosphere beneath regions of alkaline volcanism. They support the results of Meen et al. ${ }^{5}$, suggesting that these $\mathrm{CO}_{2}$-rich fluids are not significant carriers for the rare earth and perhaps other trace elements, such as strontium $^{7-9}$, in the mantle lithosphere.

J. STONE

D. PORCELLI

D. VANCE

S. GALER

R. K. O'NIONS

Department of Earth Sciences,

University of Cambridge,

Downing Site,

Cambridge CB2 $3 E Q$, UK

1. Frey, F.A. \& Green, D.H. Geochim. cosmochim. Acta 38 1023-1059 (1974).

2. Menzies, M.A., Rogers, N., Tindle, A. \& Hawkesworth, C.J. in Mantle Metasomatism (eds Menzies, M.A. \& Hawkesworth, C.J.) 313-361 (Academic, London, 1987)

3. Mysen, B.O. Neues Jb. Miner. Abh. 146, 41-65 (1979).

4. Wendlandt, R.F. \& Harrison, W.J. Contrib. Mineral. Petrol. 69, 409-419 (1979).

5. Meen, J.K., Eggler, D.H. \& Ayers, J.C. Nature 340, 301 303 (1989).

6. Jambon, A. Chem. Geol. 62, 131-136 (1987).

7. Porcelli, D.R., O'Nions, R.K. \& O'Reilly, S.Y. Chem. Geol 54, 237-249 (1986)

8. Vance, D., Stone, J.O.H. \& O'Nions, R.K. Earth planet. Sci. Lett. 96, 147-160 (1989)

9. Porcelli, D.R., O'Nions, R.K., Galer, S.J.G., Cohen, A.S. \& Mattey, D.P. Contrib. Mineral. Petrol. (in the press).

\title{
Hepatocytes and scatter factor
}

SIR-Scatter factor, a cytokine secreted by certain fibroblasts, enhances the movement and causes the dissociation and scattering of epithelial cells ${ }^{1-3}$, and may be involved in epithelial migration, for

Mouse scatter factor

Rat hepatocyte growth factor Rabbit hepatopoietin A Human hepatocyte growth factor Human hepatocyte growth factor

example in embryogenesis ${ }^{2}$. Mouse scatter factor has an apparent relative molecular mass of $62,000(62 \mathrm{~K})$ in non-reducing SDS gels and is composed of two subunits of $57 \mathrm{~K}$ and $30 \mathrm{~K}$ held together by disulphide bonds ${ }^{3}$. We have obtained an aminoterminal sequence of the $30 \mathrm{~K}$ subunit and notice that it is very similar to that of the smaller subunit of hepatocyte growth factor/hepatopoietin $\mathrm{A}$, a potent mitogen for rat hepatocytes which has been implicated in liver regeneration in vivo.

The sequence data suggest that scatter factor and hepatocyte growth factor/ hepatopoietin A are either the same or highly related molecular species. Either way, the relationship is intriguing. Scatter factor was identified as a motility factor and, at least in MDCK cells which are highly responsive to motility stimulation, it has little effect on DNA synthesis and no effect on the rate of cell division ${ }^{3}$. On the other hand, hepatocyte growth factor/ hepatopoietin $\mathrm{A}$ has no reported effect on cell motility.

If the scattering and mitogenic activities are due to the same protein, it is tempting to suggest that different classes of receptors mediate the effects on growth and

VVNGIPTQTTVG?MVSLLYRN?HI

Ref.

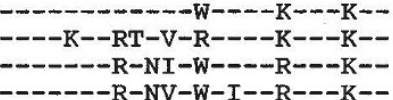

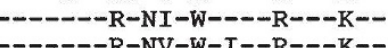

movement in different types of cells or tissues. If they are due to related but different proteins, it is clear that the two factors are members of a new group of cytokines that control both epithelial movement and growth. Coordinate regulation of cell migration and division is a key feature of many developmental processes and repair reactions.

ERMANNO GHERARDI

MRC Laboratory of Molecular Biology, Hills Road, Cambridge CB2 2QH, UK

MICHAEL STOKER

Imperial Cancer Research Fund and Department of Pathology,

University of Cambridge,

Cambridge CB2 1QP, UK

1. Stoker, M. \& Perryman, M. J. Cell Sci. 77, 209 (1985)

2. Stoker, M. et al. Nature 327, 239-242 (1987)

3. Gherardi, E. et al. Proc. natn. Acad. Sci. U.S.A. 86, 58445848 (1989).

4. Nakamura, T. et al. Nature 342, 440-443 (1989).

5. Zarnegar, R. et al. Biochem. biophys. Res. Commun. 163. 1370-1376 (1989)

6. Miyazawa, R. et al. biochem. Biophys. Res. Commun. 168, 967-978 (1989). 